\title{
SUPLEMENTASI PROBIOTIK DALAM RANSUM BASAL UNTUK MENINGKATKAN PENAMPILAN SERTA MENEKAN JUMLAH LEMAK ABDOMEN DAN GAS AMONIA EKSKRETA ITIK
}

\author{
PUSPANI, E., N. G. K. RONI, DAN I G.N. G. BIDURA \\ Program Studi Peternakan, Fakultas Peternakan, Universitas Udayana, Denpasar \\ e-mail: eny_fapet@yahoo.co.id
}

\begin{abstract}
ABSTRAK
Penelitian ini bertujuan untuk mengkaji pengaruh suplementasi kultur Saccharomyces spp. dalam ransum terhadap penampilan, jumlah lemak abdomen, dan kadar gas ammonia ekskreta itik bali umur 4-8 minggu. Rancangan yang digunakan adalah rancangan acak lengkap (RAL) dengan empat perlakuan dan enam ulangan. Keempat perlakuan yaitu ransum tanpa suplementasi kultur Saccharomyces spp. sebagai kontrol (A). Suplementasi masing-masing: 0,15\%; 30\%, dan 0,45\% kultur Saccharomyces spp. dalam ransum kontrol, masing-masing sebagai perlakuan B, C, dan D. Variabel yang diamati adalah konsumsi ransum, berat badan akhir, pertambahan berat badan, feed conversion ratio (FCR), berat karkas, lemak abdomen, dan kadar gas amonia ekskreta. Hasil penelitian menunjukkan bahwa suplementasi kultur Saccharomyces spp. dalam ransum basal pada level o,30\% (C), dan $0,45 \%(\mathrm{D})$ nyata $(\mathrm{P}<0,05)$ meningkatkan berat badan akhir, pertambahan berat badan, dan berat karkas itik jika dibandingkan dengan tanpa suplementasi (A). Akan tetapi, jumlah lemak abdomen dan kadar gas amonia ekskreta itik nyata $(\mathrm{P}<0,05)$ lebih rendah daripada kontrol. Hasil penelitian ini dapat disimpulkan bahwa suplementasi 0,30 dan $0,45 \%$ kultur isolat Saccharomyces spp ragi tape dalam ransum basal dapat meningkatkan penampilan itik bali jantan umur 4-8 minggu serta menurunkan jumlah lemak abdomen dan kadar gas amonia dalam ekskreta itik.
\end{abstract}

Kata kunci: Saccharomyces spp., penampilan, lemak abdomen, amonia, itik bali

\section{THE EFFECTS OF SUPPLEMENTING DIETS WITH Saccharomyces spp CULTURE AS A PROBIOTICS SOURCHES ON MALE BALI DRAKE PERFORMANCE, ABDOMINAL FAT, AND AMMONIA-N CONCENTRATION IN EXCRETA}

\begin{abstract}
This research was carried out to study the effects of supplementing diets with Saccharomyces spp. culture as a probiotics sources on male bali drake performance, abdominal fat, and ammonia-N concentration up to eight weeks of age. The design of experiment used a completely randomized design (CRD) with four treatments and six replications, with four birds in each replication. The fourth diets evaluated (A) ration without Saccharomyces spp. culture supplemented as a control; (B) Supplemented ration with Saccharomyces spp culture at 0.15\%, 0.30\% and $0.45 \%$ Saccharomyces spp. as treatment B, C and D. Variables observed as of feed consumptions, final body weight, live weight gains (LWG), carcass weight, abdominal-fat, FCR, and ammonia-N concentration of excreta. Results showed that supplementation of $0.30 \%$ to $0.45 \%$ Saccharomyces spp. culture in basal diets were increased significantly $(\mathrm{P}<0.05)$ on final body weight, live weight gains, and carcass weight than control diets $(\mathrm{A})$. But abdominal fat and ammonia-N concentration in excreta of birds were decreased significantly different $(\mathrm{P}<0.05)$ than control. It can be concluded that supplementation of 0.30 and $0.45 \%$ Saccharomyces spp. culture in basal diets were increased performance of male bali drake up to eight weeks of age, but decreasing abdominal-fat and ammonia-N concentration in excreta.
\end{abstract}

Key words: Saccharomyces spp, performance, abdominal-fat, ammonia-N, Bali drake 


\section{PENDAHULUAN}

Perhatian masyarakat terhadap lemak dan kolesterol menjadi semakin besar terutama setelah diketahui bahwa mengkonsumsi lemak/kolesterol yang berlebihan akan mempengaruhi kesehatan. Tidak saja terhadap peningkatan penyakit jantung koroner, tetapi akhirakhir ini diinformasikan juga terhadap penyakit kanker, diabetes, dan tekanan darah tinggi (Santoso, 2000).

Akumulasi lemak yang tinggi pada perut dan viscera akan memperkecil keuntungan yang diperoleh pabrik pasca panen dan meningkatkan masalah pengolahan limbah. Oleh karena itu, sangat bermanfaat apabila dapat menurunkan kolesterol dan lemak tubuh ayam melalui manajemen perbaikan ransum yang diberikan, yaitu dengan memanfaatkan bioteknologi probiotik. Hasil penelitian Mohan et al. (1996) menunjukkan bahwa suplementasi probiotik (L. acidophilus, L. casei, Bifidobacterium bifidum, Torulopsis, dan Aspergilus oryzae) nyata dapat meningkatkan pertumbuhan dan menurunkan serum kolesterol ayam

Disisi lain, ternyata masalah pencemaran amonia dan E. choli mendapat sorotan penting dalam dunia peternakan, karena semakin banyaknya peternakan yang intensif. Level amonia yang berlebihan dapat menurunkan produktivitas ternak ayam dan meningkatnya kepekaan terhadap serangan penyakit (Bidura et al., 2010). Untuk mengatasi hal tersebut adalah dengan menerapkan bioteknologi probiotik melalui ransum yang diberikan.

Saccharomyces cerevisiae dapat berperan sebagai mikroba probiotik dan juga dapat meningkatkan kecernaan pakan berserat tinggi (Wallace dan Newbold, l993), menjadi produk asam lemak terbang. Khamir Saccharomyces sp sebagai sumber probiotik dalam pakan bertujuan untuk meningkatkan jumlah bakteri asam laktat (BAL) yang akan mempengaruhi sejumlah proses pencernaan dan penyerapan lemak di dalam saluran pencernaan. Dalam saluran pencernaan, bakteri asam laktat mampu memanfaatkan energi yang berasal dari sumber karbohidrat untuk menurunkan $\mathrm{pH}$ saluran pencernaan menjadi 4,5 yang mengakibatkan suasana di dalam saluran pencernaan menjadi asam. Lingkungan asam menyebabkan aktivitas enzim lipase menjadi terbatas, sehingga pencernaan lemak berkurang dan selanjutnya pembentukkan lemak tubuhpun menjadi menurun (Piliang et al., l990).

Penggunaan probiotik dalam ransum dapat meningkatkan kandungan "lysine analoque S-2-aminoethylcysteine" dalam saluran pencernaan unggas (Sand dan Hankins, l996). Peningkatan kandungan asam amino lisin di dalam tubuh akan meningkatkan retensi energi sebagai protein dan dan menurunnya retensi energi sebagai lemak dalam tubuh (Sibbald dan Wolynetz, l986).
Gas amonia di dalam kandang dapat berasal dari bakteri yang mati, kotoran, dan air seni dan gas ini paling banyak mempengaruhi penampilan ayam (Arifien, 1998). Dilaporkan juga, dalam jumlah o,003\% dalam udara akan mengakibatkan $\mathrm{pH}$ darah naik, reabsorpsi oleh paru-paru, kemampuan oksidasi menurun, menekan pernafasan dan sirkulasi darah, merusak alat pernafasan dan mata.

Salah satu cara untuk menurunkan kadar gas amonia feses adalah dengan jalan menekan degradasi urea, yaitu dengan jalan memisahkan antara urin dan feses, atau dapat dilakukan dengan menggunakan urease inhibitor. Probiotik ternyata dilaporkan mampu menekan aktivitas enzim urease dapat menurunkan jumlah asam urat dalam saluran pencernaan ayam, karena asam urat sudah dimanfaatkan menjadi protein mikrobial (Chiang dan Hsieh, l995).

Beberapa hasil penelitian pendahuluan mengenai penggunaan ragi dalam ransum ternyata mampu meningkatkan penampilan, nilai guna pakan serat, dan menurunkan perlemakan tubuh unggas. Candraasih dan Bidura (2001) melaporkan bahwa penggunaan 0,50\% ragi pada ransum yang mengandung $15 \%$ cangkang coklat nyata dapat meningkatkan pertambahan berat badan itik. Demikian juga halnya dengan suplementasi ragi pada serbuk gergaji kayu dapat menurunkan jumlah lemak subkutan termasuk kulit karkas (Ariana dan Bidura, 2001). Abdulrahim et al. (1996) melaporkan bahwa penggunaan probiotik dalam ransum nyata dapat menurunkan kandungan kolesterol telur.

Dari uraian tersebut di atas, perlu kiranya dilakukan penelitian yang menggunakan khamir Saccharomyces spp yang diisolasi dari ragi tape sebagai upaya menekan jumlah lemak tubuh dan kadar gas ammonia dalam ekskreta itik.

\section{MATERI DAN METODE}

\section{Kandang dan Itik}

Kandang yang digunakan adalah kandang dengan sistem battery colony dari bilah bambu sebanyak 24 buah. Tiap petak kandang berukuran panjang 1,0 m, lebar o,40 m, dan tinggi o,40 m. Semua petak kandang terletak dalam sebuah bangunan kandang dengan atap genteng dan sudah dilengkapi dengan tempat pakan dan air minum.

Itik yang digunakan adalah itik bali jantan umur empat minggu yang diperoleh dari petani peternak itik lokal di daerah Tabanan dengan berat badan homogen.

\section{Ransum dan air Minum}

Ransum yang digunakan dalam penelitian ini dihitung berdasarkan tabel komposisi zat makanan menurut Scott et al. (1982), dengan menggunakan ba- 
han seperti: jagung kuning, tepung ikan, bungkil kelapa, dedak padi, kacang kedelai, dan garam. Semua perlakuan ransum disusun isokalori (ME: $2900 \mathrm{kcal} /$ $\mathrm{kg}$ ) dan isoprotein (CP: 17\%). Air minum yang diberikan bersumber dari perusahan air minum setempat.

\section{Saccharomyces sp.}

Probiotik Saccharomyces sp. sebagai sumber probiotik digunakan khamir Saccharomyces spp yang diisolasi dari ragi tape yang umumnya digunakan dalam pembuatan tape, merk "Na Kok Liong", terdaftar nomor 26895 yang diperoleh dari pasar umum setempat.

\section{Pemberian Ransum dan Air Minum}

Ransum perlakuan dan air minum diberikan ad libitum sepanjang periode penelitian. Penambahan ransum dilakukan 2-3 kali sehari dan diusahakan tempat ransum terisi 3/4 bagian, untuk mencegah agar ransum tidak tercecer.

Tabel 1. Komposisi bahan pakan dalam ransum itik umur 4-8 minggu

\begin{tabular}{lcccc}
\hline \multirow{2}{*}{ Bahan Pakan (\%) } & \multicolumn{5}{c}{$\begin{array}{c}\text { Suplementasi Kultur Isolat Saccharomyces spp ragi tape } \\
\end{array}$} & $\mathrm{A}$ & $\mathrm{B}$ & $\mathrm{C}$ & $\mathrm{D}$ \\
\cline { 2 - 5 } & 58,70 & 58,70 & 58,70 & 58,70 \\
\hline Jagung kuning & 12,00 & 12,00 & 12,00 & 12,00 \\
Dedak padi & 10,80 & 10,80 & 10,80 & 10,80 \\
Bungkil kelapa & 13,90 & 13,90 & 13,90 & 13,90 \\
Tepung ikan & 4,20 & 4,20 & 4,20 & 4,20 \\
Kacang kedelai & 0,40 & 0,40 & 0,40 & 0,40 \\
Garam (NaCl) & - & + & + & + \\
Saccharomyces spp & 100 & 100 & 100 & 100 \\
\hline Total & & & &
\end{tabular}

Keterangan:

1.Ransum basal tanpa suplementasi kultur isolat Saccharomyces spp ragi tape sebaga kontrol (A); dengan suplementasi 0,15\% kultur isolat Saccharomyces spp ragi tape (B); dengan suplementasi $0,30 \%$ kultur isolat Saccharomyces spp ragi tape (C); dan ransum basal dengan suplementasi $0,45 \%$ kultur isolat Saccharomyces spp ragi tape (D).

Tabel 2. Komposisi zat makanan dalam ransum itik umur 4-8 minggu ${ }^{1)}$

\begin{tabular}{|c|c|c|c|c|c|c|}
\hline \multicolumn{2}{|c|}{ Zat Makanan } & \multicolumn{4}{|c|}{$\begin{array}{c}\text { Suplementasi Kultur Isolat } \\
\text { Saccharomyces spp ragi tape (\%) }\end{array}$} & \multirow[t]{2}{*}{ Standar ${ }^{2}$} \\
\hline & & A & B & C & $\mathrm{D}$ & \\
\hline Energi termetabolis & (kkal/kg) & 2900 & 2900 & 2900 & 2900 & 2900 \\
\hline Protein kasar & $(\%)$ & 17,02 & 17,02 & 17,02 & 17,02 & 17.00 \\
\hline Serat kasar & $(\%)$ & 4,58 & 4,58 & 4,58 & 4,58 & $5-7$ \\
\hline Lemak kasar & $(\%)$ & 6,05 & 6,05 & 6,05 & 6,05 & $5-10$ \\
\hline $\mathrm{Ca}$ & (\%) & 1,13 & 1,13 & 1,13 & 1,13 & $0.8-1.2$ \\
\hline P-tersedia & $(\%)$ & 0,66 & 0,66 & 0,66 & 0,66 & 0.40 \\
\hline Arginin & $(\%)$ & 1,43 & 1,43 & 1,43 & 1,43 & 1.00 \\
\hline Lysin & $(\%)$ & 1,28 & 1,28 & 1,28 & 1,28 & 0.82 \\
\hline Metionin+sistein & (\%) & 0,78 & 0,78 & 0,78 & 0,78 & 0.60 \\
\hline
\end{tabular}

Keterangan :

1. Berdasarkan perhitungan Scott et al. (1982)

2. Berdasarkan standar Farrell (1995)

3. Ransum basal tanpa suplementasi kultur isolat Saccharomyces spp ragi tape sebagai kontrol (A); dengan suplementasi 0,15\% kultur isolat Saccharomyces spp ragi tape (B); dengan suplementasi 0,30\% kultur isolat Saccharomyces spp ragi tape (C); dan ransum basal dengan suplementasi $0,45 \%$ kultur isolat Saccharomyces spp ragi tape (D);

\section{Rancangan Percobaan}

Rancangan yang digunakan dalam penelitian ini adalah rancangan acak lengkap (RAL) dengan empat perlakuan dan enam ulangan. Tiap ulangan (unit percobaan) menggunakan 8 ekor itik bali jantan umur empat minggu dengan berat badan homogen. Keempat perlakuan yang dicobakan adalah: ransum basal tanpa penambahan Saccharomyces spp sebagai kontrol (A); ransum dengan penambahan 0,15\% Saccharomyces spp (B); ransum dengan penambahan 0,30\% Saccharomyces spp (C); dan Ransum dengan penambahan 0,45\% Saccharomyces spp (D).

\section{Variabel yang Diamati}

Variabel yang diamati dalam penelitian ini adalah: konsumsi ransum, berat badan itik, pertambahan berat badan, lemak abdominal (merupakan gabungan antara lemak yang ada ada di sekitar saluran pencernaan, lemak bantalan dan lemak empedal).

\section{Kadar N-NH $\mathrm{NH}_{3}$ ekskreta}

Kadar $\mathrm{N}^{-\mathrm{NH}_{3}}$ ekskreta: penentuan kadar $\mathrm{N}-\mathrm{NH}_{3}$ dengan menggunakan difusi Conway (Saransi et al., 2010) sebagai berikut: $1 \mathrm{ml}$ sampel supernatant disebelah kiri sekatan cawan Conway, $1 \mathrm{ml}$ larutan $\mathrm{Na}_{2} \mathrm{CO}_{3}$ jenuh pada sekat sebelah kanan, $1 \mathrm{ml} \mathrm{H}_{3} \mathrm{BO}_{3}$ $2 \%$ yang berindikator $\mathrm{BCG}+\mathrm{MR}$ pada cawan tengah, kemudian tutup cawan conway bervaselin dengan rapat, goyang dengan perlahan sampai supernatant dengan $\mathrm{Na}_{2} \mathrm{CO}_{3}$ bercampur sempurna, kemudian biarkan 24 jam dalam suhu kamar, selanjutnya lakukan titrasi dengan menggunakan $\mathrm{H}_{2} \mathrm{SO}_{4}$ o,o05 $\mathrm{N}$ sampai titik akhir titrasi. Kadar $\mathrm{N}-\mathrm{NH}_{3}$ dapat dihitung sebagai berikut ini: mM N-NH3 = (Volume titrasi $\left.x \mathrm{NH}_{2} \mathrm{SO}_{4} \times 1.00 \%\right)$

\section{Analisis Statistika}

Data yang diperoleh di analisis dengan sidik ragam dan apabila terdapat perbedaan yang nyata $(\mathrm{P}<0,05) \mathrm{di}$ antara perlakuan, maka dilanjutkan dengan uji jarak berganda dari Duncan (Steel and Torrie, 1989).

\section{HASIL DAN PEMBAHASAN}

\section{Berat Badan Akhir}

Rataan berat badan akhir itik yang diberi ransum basal tanpa suplementasi kultur isolat Saccharomyces spp ragi tape sebagai kontrol (A) adalah 952,37 g/ekor (Tabel 3) dan tidak menunjukkan perbedaan yang nyata $(\mathrm{P}>0,05)$ dengan berat badan itik yang diberi ransum basal dengan suplementasi $0,15 \%$ kultur isolat Saccharomyces spp ragi tape (B). Rataan berat badan akhir itik yang diberi ransum dengan suplementasi 0,30\% kultur isolat Saccharomyces spp ragi tape (C); dan ransum basal dengan suplementasi $0,45 \%$ kultur 
isolat Saccharomyces spp ragi tape (D), masing-masing adalah: $12,72 \%$ dan $13,51 \%$ nyata $(\mathrm{P}<0,05)$ lebih tinggi daripada kontrol.

Suplementasi kultur isolat Saccharomyces spp ragi tape dalam ransum basal nyata dapat meningkatkan berat badan akhir itik. Hal ini logis karena kultur Saccharomyces spp. yang digunakan dalam penelitian ini mampu berperan sebagai agensia probiotik dalam saluran pencernaan itik (Bidura, 2012). Han et al. (2001) melaporkan bahwa Aspergillus oryzae dan $S$. cereviseae dapat meningkatkan aktivitas enzim amilolitik dan proteolitik dalam saluran pencernaan ayam, sehingga dapat meningkatkan kecernaan protein dan energi termetabolis. Meningkatnya kecernaan protein dan energi termetabolis akan berdampak pada peningkatan berat badan itik.

\section{Pertambahan Berat Badan}

Hasil penelitian mendapatkan bahwa pertambahan berat badan itik kontrol (A) selama empat minggu adalah 602,81 g/ekor/4 minggu (Tabel 3) dan tidak berbeda nyata $(\mathrm{P}>0,05)$ dengan itik perlakuan $\mathrm{B}$. Sebaliknya, pertambahan berat badan itik perlakuan C dan D masing-masing adalah: $19,26 \%$ dan $21,22 \%$ nyata lebih tinggi daripada kontrol.

Adanya probiotik dalam ransum pada level $0,30 \%$ dan $0,45 \%$ akan dapat meningkatkan aktivitas enzim pencernaan. Sebagai konsekuensi logis, akan meningkatkan pertambahan berat badan ayam. Dilaporkan oleh Piao et al. (1999), bahwa suplementasi probiotik dalam ransum nyata dapat meningkatkan pertambahan berat badan, pemanfaatan zat makanan, serta kecernaan nitrogen dan phosphor. Dilaporkan juga oleh Stanley et al. (1993), ayam broiler yang diberi Saccharomyces cerevisiae 0,10\% nyata meningkatkan pertambahan berat badan dan efisiensi penggunaan ransum.

\section{Konsumsi Ransum}

Ransum yang dikonsumsi oleh itik perlakuan kontrol selama empat minggu adalah 2817,73 g/ekor/4 minggu (Tabel 3). Rataan konsumsi ransum oleh itik yang diberi perlakuan B, C, dan D ternyata tidak menunjukkan perbedaan yang nyata $(\mathrm{P}>0,05)$. Suplementasi $0,1^{-}$ $0,45 \%$ kultur isolat Saccharomyces spp ragi tape ke dalam ransum sebagai sumber probiotik, ternyata tidak berpengaruh terhadap jumlah ransum yang dikonsumsi. Hal ini logis karena kandungan energi dalam ransum keempat perlakuan adalah sama. Seperti dilaporkan oleh Wahju (1988), faktor utama yang mempengaruhi banyaknya ransum yang dikonsumsi pada unggas adalah kandungan energi dalam ransum. Namun demikian ada kecenderungan terjadi peningkatan konsumsi ransum dengan adanya probiotik dalam ransum. Hal ini disebabkan karena keberadaan kultur isolat Saccharomyces spp ragi tape sebagai sumber probiotik dalam ransum dapat meningkatkan aktivitas enzimatis dan proses pencernaan pada ayam (Jin et al., 1997), juga dapat menurunkan kadar gas amonia dalam ekskreta maupun dalam litter (Chiang dan Hsieh, l996), sehingga ayam akan merasa lebih nyaman, dan dalam keadaan nyaman ayam akan meningkatkan konsumsi ransum dan zat-zat makanan lainnya untuk mendukung proses produksi. Disamping itu, probiotik dapat berperan sebagai sumber vitamin B kompleks (Sukaryani, l997).

\section{Feed Conversion Ratio (FCR)}

Rataan nilai FCR selama empat minggu pengamatan pada itik yang diberi perlakuan kontrol adalah 4,67/ ekor/4 minggu (Tabel 3) dan tidak menunjukkan berbeda nyata $(\mathrm{P}>0,05)$ dengan nilai $\mathrm{FCR}$ pada itik yang mendapat perlakuan $\mathrm{B}$. Rataan nilai FCR pada itik yang mendapat perlakuan $\mathrm{C}$ dan $\mathrm{D}$, masing-masing adalah: $13,49 \%$ dan $13,70 \%$ nyata $(\mathrm{P}<0,05)$ lebih rendah daripada nilai FCR itik kontrol.

Feed conversion ratio (FCR) merupakan salah satu indikator yang dapat memberikan gambaran tentang tingkat efisiensi penggunaan ransum. Semakin rendah nilai $F C R$, maka semakin tinggi tingkat efisiensi penggunaan ransumnya. Suplementasi kultur isolat Saccharomyces spp ragi tape dalam ransum ternyata dapat meningkatkan efisiensi penggunaan ransum. Hal ini dimungkinkan karena keberadaa probiotik dalam ransum dapat meningkatkan aktivitas enzimatis dan aktivitas pencernaan (Jin et al., 1997). Hal tersebut akan dapat meningkatkan kecernaan ransum, kecernaan protein, dan mineral fosfor (Piao et al., l999). Ragi/ khamir dalam saluran pencernaan unggas dapat meningkatkan sekresi mucin. Mucin merupakan zat yang sangat penting artinya bagi habitat dan sumber zat makanan bagi mikrobia yang menguntungkan dalam saluran pencernaan ayam (Savage, 1991). Menurut Chesson (1994), respons pemberian probiotik pada ternak berbeda pengaruhnya, dan hal tersebut sangat dipengaruhi oleh strain bakteri yang digunakan sebagai probiotik, dosis atau level pemberiannya, komposisi ransum, sistem pemberian pakan, bentuk ransum, dan interaksi dengan feed additive lainnya. Dilaporkan oleh Bradley et al. (1994), bahwa penggunaan 0,01-0,06\% $S$. cereviseae dalam ransum nyata dapat menurunkan jumlah sel goblet, meningkatkan tinggi villus, dan efisiensi penggunaan ransum. Berkurangnya sel goblet, menurut Basyir (1999) menyebabkan berkurangnya lendir yang dihasilkan sehingga proses penyerapan zatzat makanan oleh usus meningkat, karena lendir dari sel goblet di dalam saluran pencernaan ayam dapat menghambat proses absorpsi nutrisi. 
Dilaporkan juga oleh Piliang (1997), bahwa penggunaan Aspergillus niger dalam ransum dapat berperan sebagai pemecah ikatan kompleks mineral-mineral yang terikat oleh asam fitat, dan pada dedak padi mampu meningkatkan kadar protein dan ketersediaan mineral Ca, P, dan Mg. Hasil penelitian ini sesuai dengan hasil penelitian dari Sudiastra (1999), serta Suryani dan Bidura (l999) dan Park et al. (1994) melaporkan bahwa penggunaan probiotik dalam ransum dapat meningkatkan pertambahan berat badan, feed intake, dan efisiensi penggunaan ransum ayam. Pemberian kultur isolat Saccharomyces spp sebagai sumber probiotik dalam saluran pencernaan ternak unggas dapat memacu perbaikan metabolisme pakan pada proses pencernaan (Nurhayati, 2008). Tang et al. (2007) menyatakan bahwa peningkatan konsumsi protein dan asam amino lysin pada ayam broiler menyebabkan peningkatan jumlah daging dada dibandingkan dengan konsumsi protein dan lysin yang lebih rendah.

Tabel 3. Pengaruh suplementasi probiotik dalam ransum basal terhadap penampilan serta jumlah lemak abdomen dan gas amonia ekskreta itik umur 4-8 minggu

\begin{tabular}{|c|c|c|c|c|c|}
\hline \multirow{2}{*}{ Variabel } & \multicolumn{4}{|c|}{ Perlakuan $^{1)}$} & \multirow{2}{*}{ SEM $^{2)}$} \\
\hline & A & B & $\mathrm{C}$ & $\mathrm{D}$ & \\
\hline Berat Badan Akhir (g) & $952,37 b^{3)}$ & $961,72 b$ & $1073,54 a$ & $1081,05 a$ & 31,058 \\
\hline $\begin{array}{l}\text { Pertambahan berat } \\
\text { Badan }(\mathrm{g})\end{array}$ & $602,81 b$ & $608,64 b$ & $718,91 a$ & $730,74 a$ & 29,702 \\
\hline Kosumsi Ransum (g) & $2817,73 a$ & $2831,06 a$ & $2907,42 a$ & $2945,37 a$ & 64,902 \\
\hline $\begin{array}{l}\text { Feed Conversion Ratio } \\
\text { (FCR) }\end{array}$ & $4,67 a$ & $4,65 a$ & $4,04 b$ & $4,03 b$ & 0,172 \\
\hline $\begin{array}{l}\text { Abdominal-Fat (\% Brt. } \\
\text { Potong) }\end{array}$ & $2,51 a$ & $2,54 a$ & $2,25 b$ & $2,27 b$ & 0,063 \\
\hline $\begin{array}{l}\text { Kadar N-NH } \mathrm{NH}_{3} \text { ekskreta } \\
\text { (m.Mol/liter ekskreta) }\end{array}$ & $12,092 a$ & $11,985 a$ & $10,053 b$ & $10,106 b$ & 0,495 \\
\hline \multicolumn{6}{|c|}{$\begin{array}{l}\text { Keterangan: } \\
\text { 1. Ransum basal tanpa suplementasi kultur isolat Saccharomyces spp ragi tape sebagai } \\
\text { kontrol (A); dengan suplementasi } 0,15 \% \text { kultur isolat Saccharomyces spp ragi tape } \\
\text { (B); dengan suplementasi } 0,30 \% \text { kultur isolat Saccharomyces spp ragi tape (C); dan } \\
\text { ransum basal dengan suplementasi } 0,45 \% \text { kultur isolat Saccharomyces spp ragi tape } \\
\text { (D); } \\
\text { 2. Standard Error of The Treatment Means } \\
\text { 3. Nilai dengan huruf yang berbeda pada baris yang sama, menunjukkan perbedaan } \\
\text { yang nyata }(\mathrm{P}<0,05)\end{array}$} \\
\hline
\end{tabular}

\section{Abdominal-Fat}

Rataan jumlah lemak abdomen pada itik perlakuan A adalah $2,51 \%$ berat badan (Tabel 3) dan tidak menunjukkan adanya perbedaan yang nyata $(\mathrm{P}>0,05)$ dengan perlakuan $\mathrm{B}$ akan tetapi rataan jumlah lemak abdomen pada itik perlakuan $\mathrm{C}$ dan D adalah: $10,36 \%$ dan $9,56 \%$ nyata $(\mathrm{P}<0,05)$ lebih tinggi daripada kontrol.

Suplementasi $0,30-0,45 \%$ kultur isolat Saccharomyces spp ragi tape dalam ransum basal nyata menurunkan jumlah lemak abdomen dalam tubuh itik. Terjadinya penurunan jumlah lemak abdomen (abdominal-fat) itik sebagai akibat mengkonsumsi ransum yang mengandung kultur Saccharomyces spp. sebagai sumber probiotik. Menurut Mohan et al. (1996), peng- gunaan Lactobacillus acidophilus, Lactobacillus casei, Bifidobacterium bifidum, Torulopsis, dan Aspergilus oryzae sebagai sumber probiotik dalam ransum nyata meningkatkan pertumbuhan dan menurunkan serum kolesterol ayam. Penurunan tersebut juga disebabkan karena adanya senyawa hasil dari produk fermentasi mikroba probiotik dalam saluran pencernaan ayam dapat menghambat sintesis lipida di dalam hati. Seperti dilaporkan oleh Tanaka et al. (1992) bahwa penggunaan bahan pakan produk fermentasi dapat menekan aktivitas enzim 3-hydroxy-3-methylglutaryl-CoA reduktase yang berfungsi untuk sintesis kolesterol atau lipida di dalam hati.

\section{Kadar N-Amonia Ekskreta}

Kadar N-amonia dalam ekskreta itik kontrol adalah 12,092 m.Mol/liter (Tabel 3) dan tidak menunjukkan perbedaan yang nyata $(\mathrm{P}>0,05)$ dengan perlakuan $\mathrm{B}$. Rataan kadar N-amonia dalam ekskreta ayam perlakuan C dan D secara berturutan adalah: $16,86 \%$ dan $16,42 \%$ nyata $(\mathrm{P}<0,05)$ lebih rendah daripada kontrol.

Penurunan kadar $\mathrm{N}^{-\mathrm{NH}_{3}}$ pada ekskreta itik yang diberikan ransum mengandung probiotik tersebut, menurutYeodan Kim (1997) disebabkan karena probiotik dalam ransum (Lactobacillus cassei) dapat menekan aktivitas enzim urease dalam usus kecil, sehingga kadar gas organik dalam ekskreta menurun. Menurut Chiang dan Hsieh (1995), penurunan kandungan gas organik ekskreta tersebut karena probiotik dapat meningkatkan kecernaan protein pakan dan dapat menurunkan jumlah asam urat. Asam urat tersebut dimanfaatkan menjadi protein organik, sehingga keberadaannya di dalam ekskreta menurun. Piao et al. (1999) menyatakan bahwa penggunaan Saccharomyces serevisiae 0,10\% dalam ransum nyata dapat menurunkan jumlah nitrogen dan fosfor yang disekresikan dalam feses ayam. Dilaporkan juga oleh Han et al. (1999), bahwa suplementasi Aspergillus oryzae dan S.cerevisiae dalam ransum basal secara signifikan dapat meningkatkan jumlah bakteri asam laktat (BAL) serta menurunkan jumlah bakteri E.choli dan bakteri aerobik dalam ekskreta. Bakteri asam laktat sangat survive dalam saluran pencernaan ternak unggas, dan hal inilah yang dapat menyebabkan jumlah bakteri E.choli dan kadar $\mathrm{N}^{-\mathrm{NH}_{3}}$ dalam ekskreta menurun. Hasil penelitian ini didukung oleh Puspani et al. (2014) yang mendapatkan bahwa suplementasi ragi dalam ransum yang mengandung pollard nyata dapat meningkatkan enampilan dan menurunkan kandungan gas ammonia dalam ekskreta ayam broiler. Hal yang sama dilaporkan oleh Bidura et al. (2014), bahwa suplementasi kultur Saccharomyces spp yang diisolasi dari feses sapi Bali sebanyak 0,20\% dalam ransum nyata dapat meningkatkan penampilan dan menurunkan kadar gas ammonia ekskreta broiler. 
Salah satu cara untuk menurunkan kadar gas amonia feses adalah dengan jalan menekan degradasi urea, yaitu dengan jalan memisahkan antara urine dan feses, atau dapat dilakukan dengan menggunakan urease inhibitor. Nico dan Jongbloed (1999) melaporkan bahwa kadar gas organik dapat diturunkan dengan menurunkan imbangan $\mathrm{N}$-urine dan $\mathrm{N}$-feses dengan jalan menambahkan karbohidrat dalam ransum. Fermentasi bahan organik pada saluran pencernaan akan meningkatkan ekskresi $\mathrm{N}$ pada feses, akan tetapi akan menurunkan sekresi $\mathrm{N}$ dari urine. Chen et al. (2005) melaporkan bahwa suplementasi probiotik kompleks ke dalam ransum secara nyata meningkatkan pertambahan berat badan dan menurunkan kadar $\mathrm{N}-\mathrm{NH}_{3}$ feses. Suplementasi $0,30-0,45 \%$ kultur isolat Saccharomyces spp ragi tape dalam ransum basal nyata menurunkan kadar $\mathrm{N}_{-} \mathrm{NH}_{3}$ ekskreta itik. Probiotik dilaporkan mampu menekan aktivitas enzim urease dan dapat menurunkan jumlah asam urat dalam saluran pencernaan ayam, karena asam urat sudah dimanfaatkan menjadi protein mikrobial (Chiang dan Hsieh, 1995).

\section{SIMPULAN}

Dari hasil penelitian ini dapat disimpulkan bahwa suplementasi 0,30 dan 0,45\% kultur isolat Saccharomyces spp ragi tape dalam ransum basal dapat meningkatkan penampilan itik bali jantan umur 4-8 minggu serta menurunkan jumlah lemak abdomen dan kadar gas amonia dalam ekskreta itik

\section{UCAPAN TERIMAKASIH}

Pada kesempatan ini penulis mengucapkan banyak terimakasih kepada Rektor Universitas Udayana, dan Dekan Fakultas Peternakan, Universitas Udayana, Denpasar atas dana yang diberikan melalui dana DIPA PNBP Universitas Udayana TA 2015. Ucapan terimakasih disampaikan kepada Sdr. Andi Udin Saransi, SPt. dan Putu Ariwati, MSi yang telah banyak membantu dalam analisis sampel.

\section{DAFTAR PUSTAKA}

Abdulrahim, S.M., M.S.Y. Haddadin, E.A.R. Haslamoun and R.K. Robinson. 1996. The influence of Lactobacillus acidhophilus and bacitracin on layer performance of chickens and cholesterol content of plasma and egg yolk. British Poult. Sci. 37: 341 - 346.

Ahmad, R. Z 2005. Pemanfaatan khamir Saccharomyces cerevisiae untuk ternak. Wartazoa Vol. 15 (1): 49-55

Ariana, I. N. T. dan I G.N.G. Bidura. 2001. Bobot dan komposisi fisik karkas ayam broiler yang diberi ransum dengan penambahan serbuk gergaji kayu, ragi tape dan kombinasinya. Majalah Ilmiah Peternakan 4 (1): 21-26 Arifien, M. 1998. Mengurangi gas yang merugikan di Kandang. Poultry Indonesia Edisi Desember 1998, No: 224, Hal: 32-33

Basyir, A. K. 1999. Serat kasar dan pengaruhnya pada broiler. Poultry Indonesia. Okt. 99 No. 233, Hal: 43-45

Bidura, I.G.N.G. 2012. Isolasi, Identifikasi dan Uji Kemampuan Khamir Saccharomyces cerevisiae yang Diisolasi dari Ragi Tape sebagai Agensia Probiotik dan Peningkatan Produktivitas Itik Bali. Disertasi, Program Studi Doktor Ilmu Ternak, Program Pascasarjana, Universitas Udayana, Denpasar

Bidura, IGNG., DPMA. Candrawati, and DA. Warmadewi. 2010. Pakan Unggas. Konvensional dan Inkonvensional. Udayana University Press, Denpasar.

Bidura, IGNG., DPMA. Candrawati, and DA. Warmadewi. 2014. Implementation of Saccharomyces spp.S-7 isolate (Isolated from manure of Bali cattle) as a probiotics agent in diets on performance, blood serum cholesterol, and ammonia-N concentration of broiler excreta. International Journal of Research Studies in Biosciences (IJRSB) September Vol. 2 (8): 6-16

Bradley, G. L., T. F. Savage and K. I. Timm. 1994. The effects of supplementing diets with Saccharomyces sereviseae var. Boulardii on male poult performance and ileal morphology. Poult. Sci. 73: 1766 - 1770

Candraasih, N.N.K. dan I G.N.G. Bidura. 2001. Pengaruh penggunaan cangkang kakao yang disuplementasi ragi tape dalam ransum terhadap penampilan itik bali. Majalah Ilmiah Peternakan 4 (3): 67-72.

Chen, Y. H., H. K. Hsu, and J. C. Hsu. 2005. Studies on the fine structure of caeca in domestic geese. AJAS 15 (7): 1018-1021

Chesson, A. 1994. Probiotics and Other Intestinal Mediators. In: (Ed. D.J.A. Cole, J. Wiseman, and M.A. Varley) Principles of Pig Science. Loughborgough, UK: Nottingham University Press. Pp. 197-214.

Chiang, S.H., and W.M. Hsieh. 1995. Effect of direct feed microorganisms on broiler growth performance and litter ammonia level. AJAS 8: 159-162

Corzo, G. and S. E. Gilliland. 1999. Bile salt hydrolase activity of there strain of Lactobacillus acidhophilus. J. Dairy Sci. 82: 472-479

Han, I. K., J. H. Lee, X. S. Piao, and D. Li. 2001. Feeding and management system to reduce environmental pollution in swine production. Asian-Aust. J. Anim. Sci. 14: 432-444

Harianto. 1996. Manfaat Serat Makanan. Sadar Pangan dan Gizi Vol. 5 (2): 4-5

Jin, L. Z., Y. W. Ho, N. Abdullah and S. Jalaludin. 1997. Probiotics in Poultry: modes of action. Worlds Poultry Sci. J. 53 (4): 351-368

Mayes. P. A., D. K. Granner, Y. W Rodwel dan D. W. Martini. 1992. Biokimia Harper Review of Biochemestry. Edisi 20. Jakarta: Penerbit Buku Kedokteran Cetakan ke-6, EGC.

Mohan, B., R. Kadirvel, M. Bhaskaran and A. Natarajan. 1995. Effect of probiotic suplementation on serum and yolk kolesterol and egg shell thicness in layers. British Poultry Sci. 36: 799- 803

Nico, P. L. and A. W. Jongbloed. 1999. New technologies in 
low pollution swine diets: diet manipulation and use of synthetic amino acids, phytase and phase feeding for reduction of nitrogen and phosphorus excretion and ammonia emission. AJAS 12 (2): 305-327

Nurhayati. 2008. Pengaruh tingkat penggunaan campuran bungkil inti sawit dan onggok yang difermentasi dengan Aspergillus niger dalam pakan terhadap bobot dan bagian-bagian karkas broiler. Animal Production Vol 10 (1): 55-59

Park, H. Y., I. K. Han and K. N. Heo. 1994. Effects of supplementation of single cell protein and yeast culture on growth performance in broiler chicks. Kor. J. Anim. Nutr. Feed 18 (5): 346-351

Piao, X. S., I. K. Han, J. H. Kim, W. T. Cho, Y. H. Kim, and C. Liang. 1999. Effects of kemzyme, phytase, and yeast supplementation on the growth performance and pullution reduction of broiler chicks. Asian-Aust. J. Anim. Sci. 12 (1): 36-41

Piliang, W. G. 1990. Strategi Penyediaan Pakan Ternak Berkelanjutan Melalui Pemanfaatan Energi Alternatif. Orasi Ilmiah Guru Besar Tetap Ilmu Nutrisi, Fapet IPB, Bogor.

Puspani, E., IGNG. Bidura, DPMA. Candrawati, and IGA Istri Aryani. 2014. Pollard in diets supplemented with yeast on broiler performance and ammonia-N concentration of excreta. Journal of Biological and Chemical Research. September Vol. 2 (8): 6-16

Sand, D.C. and L. Hankin. 1996. Fortification of foods by fermentation with lysine-exreting mutants of Lactobacilli. J. Agric. Food Chem. 24: 1104-1106

Santoso, U. 2000. Pengaruh pemberian ekstrak daun keji beling (strobilanthes crispus bl.) terhadap performans dan akumulasi lemak pada broiler. Jurnal Peternakan dan Lingkungan 6 (2): 10-14

Saransi, A.U., T.I. Putri, I.M. Mudita, D.P.M.A. Candrawati dan I.G.N.G. Bidura. 2010. Buku Penuntun Praktikum. Laboratorium Nutrisi, Fakultas Peternakan, Universitas Udayana, Denpasar

Savage, D. C. 1991. Modes of action. Pages 11-81 In: DirectFed Microbials In Animal Production. A Review of Literature. West Des Moines, IA.: National Feed In- gradients Association

Sibbald, I.R., and M.S. Wolynetz. 1986. Effects of dietary lysine and feed intake on energy utilization and tissue synthesis by broiler chicks. Poult. Sci. 65: 98-105

Scott, M.L., M.C. Neisheim and R.J. Young. 1982. Nutrition of The Chickens. 2nd Ed. Publishing by: M.L. Scott and Assoc. Ithaca, New York.

Stanley, V. G., R. Ojo, S. Woldesenbet, D. Hutchinson and L. F. Kubena. 1993. The use of Saccharomyces sereviseae to supress the effects of aflatoxicosis in broiler chicks. Poult. Sci. 72: 1867-1872

Sukaryani, S. 1997. Ragi, bahan makanan ternak alternatif berprotein tinggi. Poultry Indonesia Nomor 205/Maret 1997. Hal: 15-16.

Suryani, N. N. dan I G.N.G. Bidura. 2000. Pengaruh suplementasi ragi tape dalam ransum terhadap kualitas fisik dan kadar kolesterol telur ayam Lohmann Brown. Majalah Ilmiah Peternakan 3 (1): 19-24

Tanaka, K., B. S. Youn, U. Santoso, S. Ohtani, and M. Sakaida. 1992. Effects of fermented feed products from chub mackerel extract on growth and carcass composition, hepatic lipogenesis and on contents of various lipid fraction in the liver and the thigh muscle of broiler. Anim. Sci. Technol. 63: $32-37$

Tang, M. Y., Q. G. Ma, X. D. Chen and C. Ji. 2007. Effects of dietary metabolizable energy and lysine on carcass characteristics and meat quality in arbor acres Broiler. AJAS Vol. 20 (12): 1865-1873

Wahju, 1989. Ilmu Nutrisi Unggas. Gadjah Mada University Press. Yogyakarta.

Wahyudi, A. dan L. Hendraningsih. 2007. Probiotik. Konsep, Penerapan, dan Harapan. Buku Ajar. Malang: Fakultas Peternakan-Perikanan, Universitas Muhammadiyah.

Wallace, R.J. and W. Newbold. 1993. Rumen Fermentation and Its Manipulation: The Development of Yeast Culture as Feed Additive. p: 173-192, In. T.P. Lyons Ed. Biotechnology in The Feed Industry Vol. IX. Altech Technical Publ. Nicholsville, KY.

Yeo, J. and K. Kim. 1997. Effect of feeding diets containing antibiotics, a probiotic or Yucca extract on growth and intestinal urease activity in broiler chicks. Poult. Sci. 76: $381-385$ 